\title{
Studi Morfometri dan Tingkat Kematangan Telur Kepiting Bakau (Scylla sp.) di Kawasan Perairan Demak
}

\author{
Edi Wibowo*, Suryono, R. Ario, Ali Ridlo dan Dodik S. Wicaksono \\ Departemen IImu Kelautan, Fakultas Perikanan dan IImu Kelautan, Universitas Diponegoro \\ JI. Prof. Soedarto SH. UNDIP, Tembalang, Semarang. 50275 \\ Email: ediwibowo1960@gmail.com
}

\begin{abstract}
Maturity of Mangrove Crab (Scylla sp) is a decisive factor in the life cycle of mangrove crab (Scylla sp). Human activities such as over-fishing of mangrove crab to meet market needs regardless the size is one of the causes of the reduced number of individuals in the wild. This study aims to determine the correlation between morphometric of maturity stage of mangrove crab (Scylla sp) in Kedungmutih Waters, Demak District. The study used exploratory descriptive method which site determination using purposive sampling methods. The research consisted of female mangrove crab sampling and field water quality measurement (DO, temperature, salinity, and $\mathrm{pH}$ ), morphometric measurements and weighing body weight of female mangrove crab samples, and observation of maturity stage in the laboratory. The material used in this study were female mud crab (Scylla sp) obtained from Kedungmutih Waters, Demak District. The results of this study showed that 94 female mangrove crabs crabs were found to have a carapace width ranging from $77.50 \mathrm{~mm}-126.45 \mathrm{~mm}$, for body weight ranging from 87 grams to 359.78 grams. While the fecundity stage were obtained from the stage of I IV and on the size of 200 grams - 300 grams has an optimal fecundity stage on the stage II and III. There is correlation between morphometry and maturity stage of mangrove crab (Scyla sp) because when the weight of crabs increases, so does the addition of the number of eggs and also improvement of egg (gonads).
\end{abstract}

Keywords: Scylla sp, Morphometry, Demak, Maturity

\begin{abstract}
Abstrak
Kematangan telur pada Kepiting Bakau betina (Scylla sp) adalah faktor yang menentukan pada siklus hidup Kepiting Bakau (Scylla sp). Kegiatan manusia seperti penangkapan kepiting bakau yang tinggi untuk memenuhi kebutuhan pasar tanpa melihat ukuran yang ditangkap merupakan salah satu penyebab berkurangnya jumlah individu yang berada di alam. Penelitian ini bertujuan untuk mengetahui hubungan morfometrik terhadap tingkat kematangan tekur Kepiting Bakau Betina (Scylla sp) di kawasan perairan Kedungmutih,Kabupaten Demak. Metode penelitian yang digunakan adalah metode deskriptf eksploratif dengan penentuan lokasi menggunakan purposive sampling methods. Penelitian ini terdiri dari sampling kepiting bakau betina dan pengukuran kulaitas perairan di lapangan (DO, suhu, salinitas, dan $\mathrm{pH}$ ), pengukuran morfometri dan penimbangan berat tubuh sampel kepiting bakau betina, dan pengamatan tingkat kematangan telur di laboratorium. Materi yang digunakan dalam penelitian ini adalah kepiting bakau betina (Scylla sp) yang diperoleh dari perairan Kedungmutih, Kadbupaten Demak. Hasil dari penelitian ini menunjukkan dari 94 ekor kepiting bakau betina yang didapatkan memiliki lebar karapas berkisar $77,50 \mathrm{~mm}-126,45 \mathrm{~mm}$, untuk berat tubuhnya berkisar $87 \mathrm{gram}-359,78 \mathrm{gram}$. Sedangkan pada tingkat kematangan telur didapatkan dari tingkat I - IV dan pada ukuran 200 gram - 300 gram memiliki tingkat kemmatangan telur yang optimal pada tingkat kematangan telur II dan III. Morfometri dan tingkat kematangan telur pada kepiting bakau betina (Scyla sp) memiliki hubungan dikarenakan jika pada bobot kepiting mengalami
\end{abstract}


pembesaran maka pada telur mengalami penambahan jumlah dan mengalami peningkatan telur(gonad).

Kata Kunci : Scylla sp, Morfometri, Demak, Kematangan telur

\section{PENDAHULUAN}

Kepiting bakau (Scylla sp.) merupakan sumberdaya hayati yang memiliki nilai ekonomis cukup tinggi dan digemari oleh masyarakat karena bernilai gizi tinggi (Catacutan,2002).Kepiting jenis ini merupakan potensi sumberdaya hayati yang paling banyak dicari oleh nelayan bahkan banyak yang menjadikannya sebagai tangkapan utama dikarenakan nilai ekonominya yang tinggi ,bahkan para nelayan menangkap secara berlebihan tanpa melihat ukuran serta kondisi yang dialami oleh kepiting tersebut,

Sebagian besar produksi kepiting bakau (Scylla sp.) dari perikanan tangkap di Indonesia masih mengandalkan ketersediaan di alam. Dikarenakan sampai saat ini hasil yang didapatkan dari budidaya kepiting bakau masih belum mencukupi kebutuhan pasar. Hal ini berarti masih tingginya pemanfaatan kepiting bakau yang berasal dari alam oleh masyarakat pesisir. Kondisi tersebut perlu diberikannya informasi kepada nelayan tentang morfometri dan tingkat kematangan telur kepiting bakau (Scylla sp.) agar nelayan dapat mengetahui ukuran dan kondisi yang sesuai dengan peraturan pemerintah untuk penangkapan kepiting bakau.

Perairan Kabupaten Demak merupakan salah satu wilayah yang mayoritas masyarakat pesisir nya memanfaatkan kepiting bakau. Oleh karena itu tingkat penangkapan fauna ini masih banyak dan perlu diadakannya konservasi dan pengelolaan secara berkelanjutan. Sehingga dibutuhkan informasi tentang morfometri dan tingkat kematangan telur pada kepiting bakau (scylla sp.) agar masyarakat sekitar mengerti ukuran dan kondisi kepiting bakau yang seharusnya ditangkap dan dimanfaatkan.

Penelitian ini bertujuan untuk mengetahui hubungan morfometrik terhadap tingkat kematangan telur Kepiting Bakau Betina (Scylla sp.) yang tertangkap di kawasan perairan Kedungmutih, Kabupaten Demak.

\section{MATERI DAN METODE}

Materi penelitian ini yaitu menggunakan kepiting bakau jenis Scylla sp sebanyak dengan parameter lingkungan ( $\mathrm{pH}$, suhu, salinitas, dan DO).

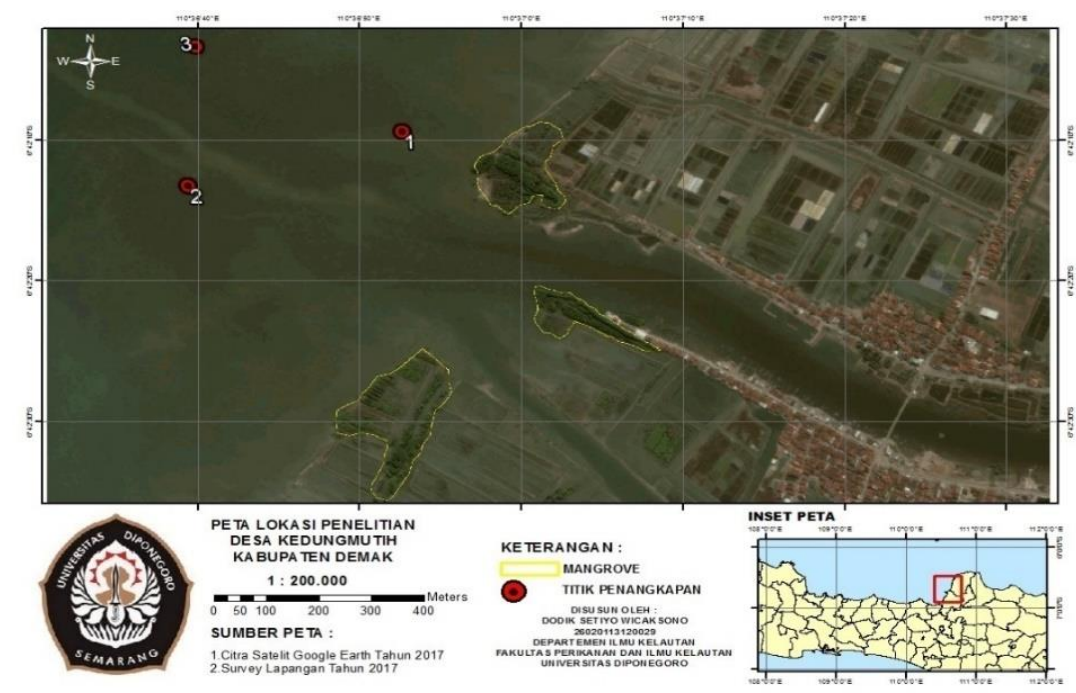

Gambar 1. Peta Lokasi Penelitian di Kawasan Perairan Desa Kedungmutih,Demak. 
Penelitian ini menggunakan metode deskriptif eksploratif yaitu metode untuk meneliti sesuatu yang belum diketahui secara pasti belum dikenali dan difahami secara baik sehingga mudah difahami dan bertujuan untuk mendapatkan data kondisi morfometrik serta kondisi kematangan telur pada Kepiting bakau betina (Scylla sp.) yang berada perairan Demak (Arikunto, 2002).

\section{Pengambilan Sampel}

Pengambilan data untuk sampling dilakukan dengan cara mendaratkan kepiting bakau yang sudah ditangkap dari 3 titik penangkapan di kawasan perairan Desa Kedungmutih. Sampel yang sudah terkumpul dilakukan pendataan panjang, lebar, berat, dan tingkat kematangan telur dari tubuh induk kepiting yang didapatkan.

Prosedur dalam pengukuran panjang dan lebar atau morfometri digunakan jangka sorong dengan tingkat ketelitian $0,01 \mathrm{~mm}$ (Overton et al., 1997),kemudian digunakan neraca analitik untuk mengukur berat tubuh dari kepiting bakau. Sedangkan untuk melihat kematangan telur dilakukan pembedahan tubuh kepiting bakau agar dapat dilihat telur yang terdapat didalam induk kepiting bakau.

\section{Pengukuran Panjang,Lebar dan Berat Kepiting Bakau (Scylla sp.)}

Pengukuran panjang dan lebar karapas dapat dilihat pada Gambar 2.

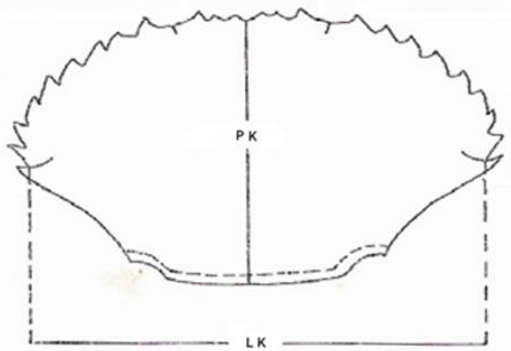

Gambar 2. Karakter Morfologi Kepiting Bakau (Scylla sp.) yang diukur (Overton et al., 1997)

Dimana :

PK : Panjang Karapas $(\mathrm{mm})$ adalah jarak antara tepi duri frontal margin dengan tepi bawah karapas
LK : Lebar Karapas $(\mathrm{mm})$ adalah jarak antara ujung duri marginal terakhir disebelah kanan dengan duri marginal terakhir di sebelah kiri

Berat tubuh ditimbang dengan timbangan analitik dengan ketelitian 0,1 gdan pengukuran panjang lebar karapasdengan menggunakan jangka sorong dengan ketelitian 0,01 $\mathrm{mm}$. Kemudian pengamatan terhadap jenis kelamin dengan cara melihat bentuk abdomen dan ukuran kepiting tersebut, dimana jantan memiliki bentuk abdomen yang mengerucutdan memiliki ukuran tubuh yang lebih kecil daibandingkan betina sedangkan betina memiliki bentuk abdomen yang melebar dan tubuh yang lebih besar daripada jantan karena pada dalam tubuh betina yang memiliki rongga perut yang lebih besar yang berfungsi sebagai tempat telur disimpan pada saat sedang bertelur.

\section{Analisis Hubungan Lebar Karapas dan Berat}

Analisis pertumbuhan lebar dan berat bertujuan untuk mengetahui pola pertumbuhan kepiting bakau di alam. Untuk mencari hubungan antara lebar dan berat total digunakan persamaan Effendie, 2002.

\section{Analisis Hubungan Morfometri dan Tingkat Kematangan Telur (Gonad)}

Hubungan morfometri dan tingkat kematangan telur (gonad) pada kepiting bakau betina analisa yang digunakan dari software Microsoft Excel dengan cara menghubungkan data morfometri yang ada dengan data tingkat kematangan telur dari kepiting bakau betina yang sudah didapat lalu dimasukkan ke dalam diagram scatter agar terlihat hubungan yang ada antara morfometri dan tingkat kematangan telur dari kepiting bakau betina yang didapat.

\section{HASIL DAN PEMBAHASAN}

Hasil pengukuran lebar karapas Scylla sp.betina diperoleh 8 kelas ukuran lebar karapas. Pembagian kelas ukuran lebar karpas ini berdasarkan jarak interval ukuran lebar karapas terendah yang di 
dapatkan nilai $77,50 \mathrm{~mm}$, dan lebar karapas tertinggi dengan nilai $126,45 \mathrm{~mm}$ dengan memiliki rentang $6,11 \mathrm{~mm}$ untuk masing-masing kelasnya, seperti yang terlihat pada Tabel 1.

Analisis yang dilakukan hubungan lebar krapas - berat Scylla sp.digunakan untuk melihat pola pertumbuhan dari Scylla sp.. Hasil dari analisis hubungan lebar karapas - berat Scylla sp. dapat dilihat pada Tabel 3.
Pada hasil kepiting bakau betina yang didapatkan memiliki jumlah kepiting TKG II dan TKG III paling banyak dikarenakan pada saat pengambilan sampel dilakukan sedang terjadi masa puncak perkawinan pada bulan Januari sampai dengan bulan Februari dimana pada bulan-bulan tersebut terjadi pergantian musim hujan menuju musim kemarau dimana suhu perairan maupun salinitas lingkungan yang ada mempengaruhi tingkat pemijahan kepiting bakau yang berada di perairan

Tabel 1. Hasil AnalisisFrekuensi Lebar Karapas Scylla sp.

\begin{tabular}{|c|c|c|c|c|c|}
\hline \multirow{2}{*}{ No } & \multirow{2}{*}{ Kelas Ukuran Lebar(mm) } & \multicolumn{2}{|c|}{ Waktu } & \multirow{2}{*}{ Jumlah (ekor) } & \multirow{2}{*}{$\begin{array}{c}\text { Presentase } \\
\text { (\%) }\end{array}$} \\
\hline & & Januari & Februari & & \\
\hline 1 & $77,50-83,61$ & 1 & 0 & 1 & $1 \%$ \\
\hline 2 & $83,62-89,73$ & 0 & 1 & 1 & $1 \%$ \\
\hline 3 & $89,74-95,85$ & 0 & 9 & 9 & $10 \%$ \\
\hline 4 & $95,86-101,97$ & 5 & 9 & 14 & $15 \%$ \\
\hline 5 & $101,98-108,09$ & 8 & 15 & 23 & $24 \%$ \\
\hline 6 & $108,10-114,21$ & 13 & 14 & 27 & $29 \%$ \\
\hline 7 & $114,22-120,33$ & 8 & 5 & 13 & $14 \%$ \\
\hline 8 & $120,34-126,45$ & 5 & 1 & 6 & $6 \%$ \\
\hline & Jumlah (ekor) & 40 & 54 & 94 & $100 \%$ \\
\hline
\end{tabular}

Tabel 2. Hasil Analisis Hubungan Lebar Karapas dan Berat Tubuh Scylla sp.

\begin{tabular}{cccccc}
\hline Waktu & Jenis Kelamin & Jumlah Sampel & $\mathrm{W}=\mathrm{aL}^{\mathrm{b}}$ & $\mathrm{r}$ & $\mathrm{R}^{2}$ \\
\hline Januari & Betina & 40 & $\mathrm{~W}=73,201 * \mathrm{~L}^{0,1537}$ & 0.9295 & 0,8639 \\
Februari & Betina & 54 & $\mathrm{~W}=75,573 * \mathrm{~L}^{0,1304}$ & 0.7858 & 0,6175 \\
Januari- Februari & Betina & 94 & $\mathrm{~W}=73,162 * \mathrm{~L} 0,1470$ & 0.8568 & 0,7340 \\
\hline
\end{tabular}

Keterangan : $W=$ Berat tubuh (gram), $L=$ Lebar Karapas $(\mathrm{mm})$, $a$ dan $b=$ Koefisien Regresi, $r=$ Koefisien Korelasi, $\mathrm{R}^{2}=$ Koefisien Determinasi

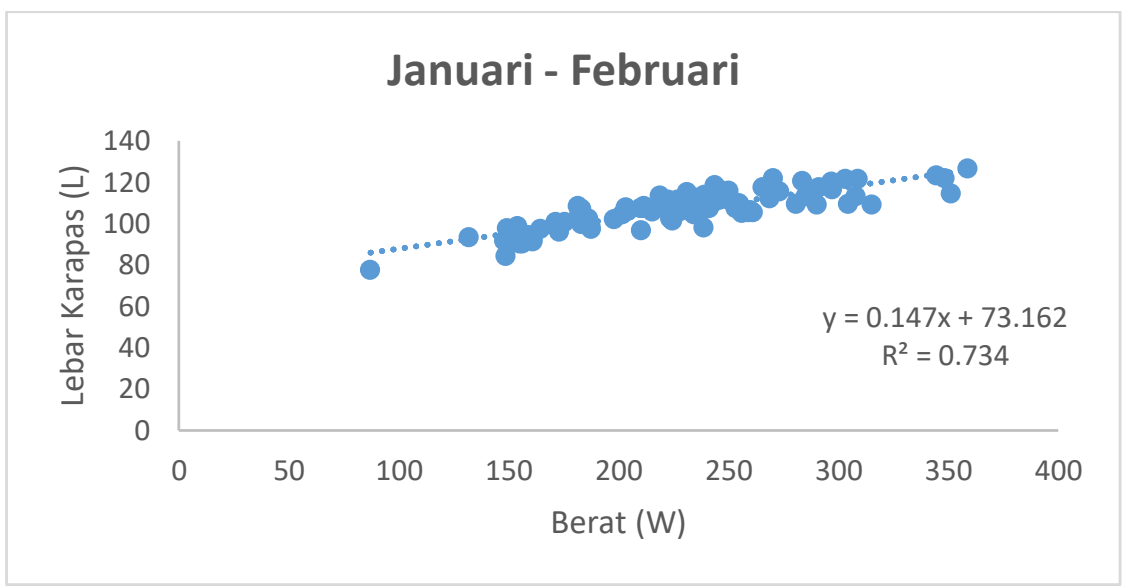

Gambar 3. Hubungan Lebar Karapas - Berat dari Scylla sp.Hasil Tangkapan di Kawasan Perairan Kedungmutih Kabupaten Demak Dari Bulan Januari - FebruariTahun 2017. 
Tabel 3. Distribusi Kelas Ukuran Berat Tubuh (gr) Kepiting Bakau Scylla sp.Betina Hasil Tangkapan di Kawasan Perairan Kedungmutih Kabupaten Demak Bulan Januari dan Februari Tahun 2017.

\begin{tabular}{|c|c|c|c|c|c|}
\hline \multirow{2}{*}{ No } & \multirow{2}{*}{ Kelas Ukuran Berat (gr) } & \multicolumn{2}{|c|}{ Waktu } & \multirow{2}{*}{ Jumlah (ekor) } & \multirow{2}{*}{ Presentase (\%) } \\
\hline & & Januari & Februari & & \\
\hline 1 & $87-121,01$ & 1 & 0 & 1 & $1 \%$ \\
\hline 2 & $121,11-155,12$ & 3 & 4 & 7 & $8 \%$ \\
\hline 3 & $155,22-189,23$ & 3 & 16 & 19 & $20 \%$ \\
\hline 4 & $189,33-223,34$ & 6 & 6 & 12 & $13 \%$ \\
\hline 5 & $223,44-257,45$ & 14 & 17 & 31 & $33 \%$ \\
\hline 6 & $257,55-291,56$ & 6 & 7 & 13 & $14 \%$ \\
\hline 7 & $291,66-325,67$ & 4 & 3 & 7 & $7 \%$ \\
\hline \multirow[t]{2}{*}{8} & $325,77-359,78$ & 3 & 1 & 4 & $4 \%$ \\
\hline & Jumlah (ekor) & 40 & 54 & 94 & $100 \%$ \\
\hline
\end{tabular}

(Kasry,1996). Hal ini dikarenakan pada musim hujan adanya zat hara yang berasal dari daratan terbawa ke laut melalui aliran sungai sehingga produktifitas perairan laut menjadi tinggi. Pada musim kemarau ketersediaan pakan alami akan meningkat yang berasal dari adanya peningkatan intensitas cahaya matahari yang tinggi menyebabkan terjadi aktifitas fotosintesa fitoplankton yang selanjutnya menghasilkan zooplankton yang menjadi pakan alami bagi larva kepiting bakau (Scylla sp.) (Siahainenia, 2008).

Tabel 3 menunjukkan bahwa distribusi frekuensi kelas ukuran berat tubuh tertinggi Scylla sp.betina hasil tangkapan di kawasan Perairan Kedungmutih, Kabupaten Demak terdapat pada interval kelas 223,44 -257,45 gr dengan modus 31 ekor atau sebesar $33 \%$ dari total yang tertangkap sebanyak 94 ekor.Sebaran frekuensi berat tubuh dimana dapat terlihat modus lebar karapas yang menggambarkan jumlah individu dari kepiting bakau yang didapatkan dapat dilihat pada Gambar 4.

Pada gambar diatas dapat dilihat hubungan berat dan tingkat kematangan telur (gonad) yang diapatkan dari data Kepiting bakau betina di kawasan perairan Kedungmutih Kabupaten Demak menunjukkan bahwa ukuran kepiting dengan berat berkisar antara 200 - 300 gram memiliki tingkat kematangan gonad yang cukup yaitu pada TKG II dan TKG III. Hal ini menunjukkan pada ukuran tersebut rata-rata kepiting bakau (Scylla sp.) sudah berada pada matang telur dan siap untuk melepaskan telurnya.

Pertumbuhan kepiting bersifat allometrik negatif yang berarti bahwa pertambahan lebar karapas lebih cepat dibandingkan berat tubuh kepiting.Sedangkan jika nilai $b<3$ menunjukan pertumbuhan yang bersifat allometrik positif yang berarti bahwa pertambahan berat tubuhnya lebih cepat dari pada lebar karapasnya.(Warner, 1977). Pada Effendie (1997) menyatakan bahwa kepiting yang memiliki pola pertumbuhan isometrik $(b=3)$, pertambahan panjangnya seimbang dengan pertambahan berat.Sebaliknya pada kepiting dengan pola allometrik $(b \neq 3)$,pertambahan panjang tidak seimbang dengan pertambahan berat.

Data morfometri dan tingkat kematangan telur (gonad) pada Kepiting Bakau (scylla sp.) akan menunjukkan bagaimana ukuran fisik dari kepiting mempengaruhi pada tingkat kematangan telur yang dialami Scylla sp. Hal ini dapat dilihat dari ukuran dan berat tubuh dari kepiting yang dihubungkan dengan tingkat kematangan telur yang dialaminya. Nilai hubungan antara morfometri dan tingkat kematangan telur (gonad) yang didapat dari data di kawasan perairan Kedungmutih Kabupaten Demak terlihat pada Gambar 3. 


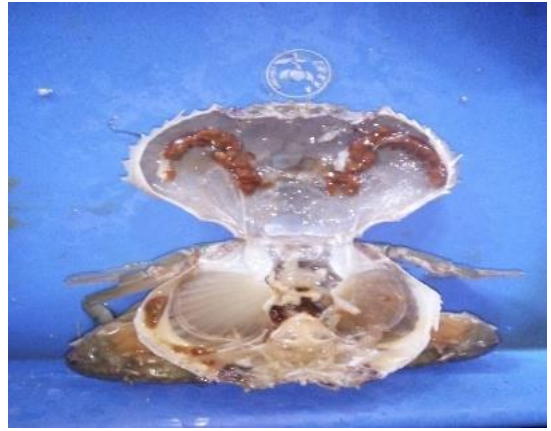

Tingkat I

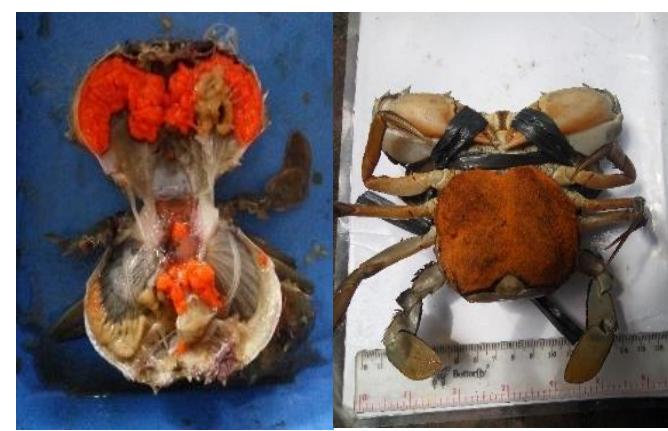

Tingkat III

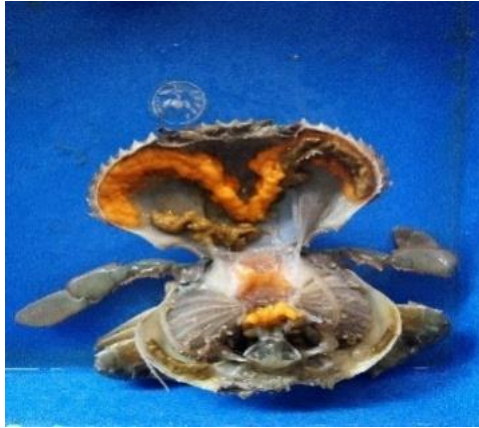

Tingkat II

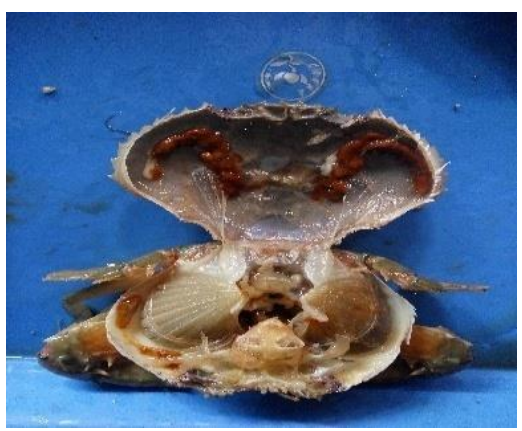

Tingkat IV

Gambar 4. Perkembangan Telur

Sumber : Penelitian (2017)

Faktor kondisi dapat menunjukkan kegemukan dari kepiting bakau,hal ini dapat dilihat dari habitat tempat kepiting tersebut hidup maupun dari kapasitas fisiknya untuk mencari makan dan untuk reproduksi.Nilai yang didapat dari data di kawasan perairan Kedungmutih Kabupaten Demak terlihat pada Tabel 4. Parameter kondisi lingkungan suhu dan salinitas memegang peran penting pada siklus kehidupan setiap makhluk hidup dan berbagai jenis biota yang ada di berbagai ekosistem, hal ini juga berlaku pada Kepiting Bakau (Scylla sp.) ( Hill, 1974).

Salinitas sangat berpengaruh pada Kepiting bakau terutama pada saat melakukan proses molting (Rosmaniar,2008). Menurut Kasry (1996) kisaran salinitas yang sesuai bagi kepiting bakau berkisar antara 10 - 30\% atau dapat digolongkan pada kondisi salinitas di air payau.

Suhu adalah salah satu faktor penting yang digunakan dalam pengkajian kelautan. Data suhu dimanfaatkan untuk mengetahui gejala - gejala fisik yang berada di laut baik yang dialami oleh hewan atau tumbuhan (Nontji, 2005). Apabila suhu pada perairan meningkat makan nafsu makan dan tingkat pertumbuhan yang terjadi pada kepiting bakau (Scylla sp.) akan meningkat .Pada suhu air yang rendah di bawah $20^{\circ} \mathrm{C}$ dapat mengakibatkan penurunan aktivitas dan nafsu makan pada kepiting bakau (Scylla sp.) (Hill, 1982). Hal ini mempengaruhi pada saat proses molting mengalami keterlambatan dan perkembangan telur pada kepiting bakau (Scylla sp.) betina yang sedikit.

Data hasil kepiting bakau betina (Scylla sp.) yang didapatkan pada kawasan perairan Kedungmutih Kabupaten Demak..Dapat dilihat pada tabel 6. Menunjukkan pada bulan Januari TKG II memiliki presentase yang paling tinggi sebesar $47 \%$ dan pada bulan Februari memiliki presentase tertinggi pada TKG III sebesar 50\%. Jika dilihat secara keseluruhan TKG II dan TKG III paling banyak didapatkan di Perairan Kedungmutih.

Pada hasil kepiting bakau betina yang didapatkan memiliki jumlah kepiting TKG II dan TKG III paling banyak 
dikarenakan pada saat pengambilan sampel dilakukan sedang terjadi masa puncak perkawinan pada bulan Januari sampai dengan bulan Februari dimana pada bulan - bulan tersebut terjadi pergantian musim hujan menuju musim kemarau dimana suhu perairan maupun salinitas lingkungan yang ada mempengaruhi tingkah pemijahan kepiting bakau yang berada di perairan (Kasry,1996). Hal ini terjadi dikarenakan pada musim hujan adanya zat hara yang berasal dari daratan terbawa ke laut melalui aliran sungai sehingga produktifitas perairan laut menjadi tinggi. Pada musim kemarau ketersediaan pakan alami akan meningkat yang berasal dari adanya peningkatan intensitas cahaya matahari

Tabel 4. Hasil Penghitungan Faktor Kondisi Kepiting Bakau (Scylla sp.)

\begin{tabular}{lccc}
\hline Kelas Lebar & Rata-Rata Lebar $(\mathrm{mm})$ & Rata-Rata Berat $(\mathrm{gr})$ & $\mathrm{Kn}$ \\
\hline $77,50-123,15$ & 106,794 & 228,8606 & 2,70905 \\
\hline
\end{tabular}

Tabel 5. Nilai Kisaran Rata-rata Parameter Lingkungan Perairan di Kawasan Perairan Kedungmutih Kabupaten Demak.

\begin{tabular}{|c|c|c|c|}
\hline \multirow[b]{2}{*}{ Parameter Lingkungan } & \multicolumn{2}{|c|}{ Kisaran } & \multirow{2}{*}{ Referensi } \\
\hline & Januari & Februari & \\
\hline Salinitas ( $\mathrm{g} / \mathrm{L}$ ) & $31,3-34,2$ & $32,3-36,8$ & 10 - 30 (Kasry,1996) \\
\hline Suhu $\left({ }^{\circ} \mathrm{C}\right)$ & $30,5-31,8$ & $31,0-32,5$ & 23 - 32 (Baliao, 1983) \\
\hline DO (mg/L) & $3,3-4,21$ & $3,21-4,17$ & $>3,0 \quad$ (Boyd, 1990) \\
\hline $\mathrm{pH}$ & $6,96-7,1$ & $6,95-7,2$ & 7,0 - 8,0 (Kasry, 1996) \\
\hline
\end{tabular}

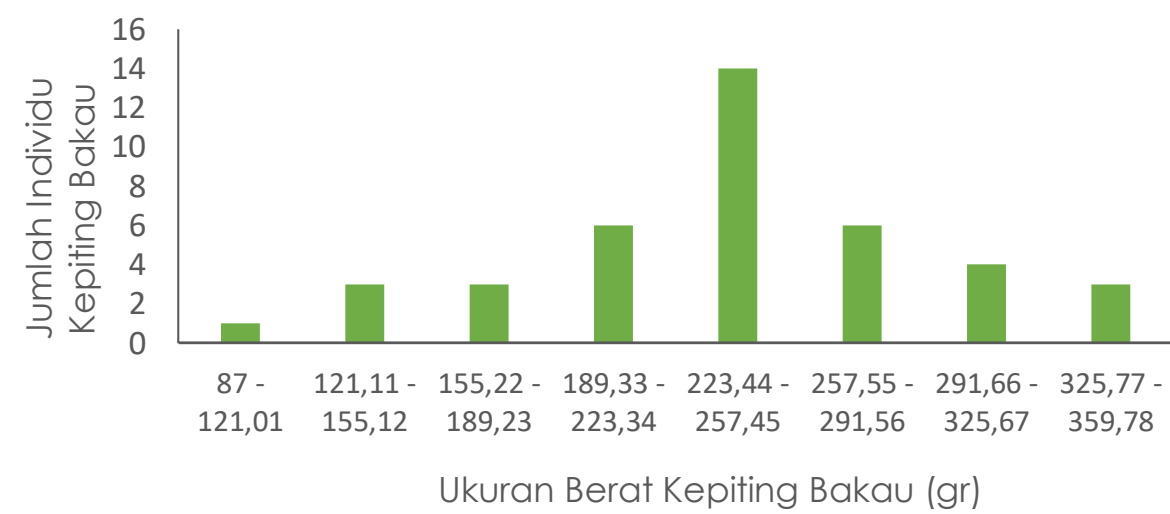

(a)

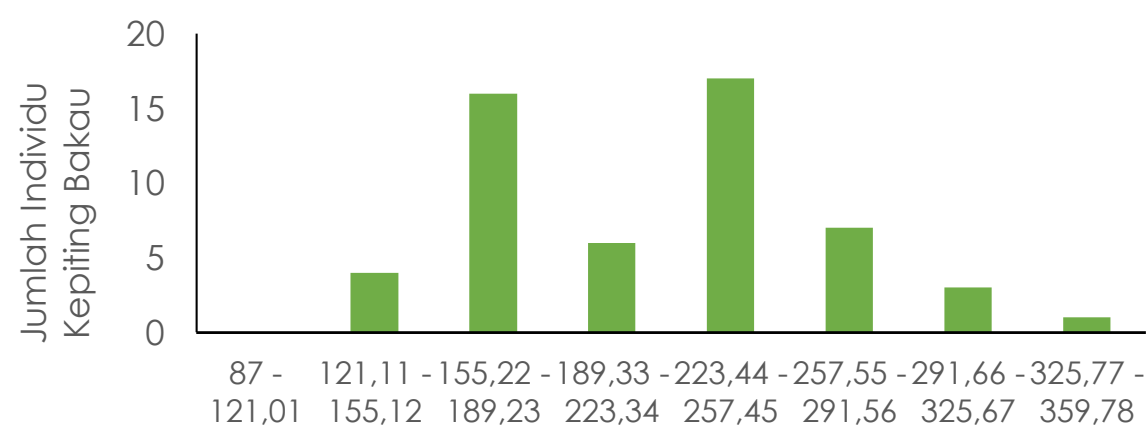

Ukuran Berat Kepiting Bakau (gr)

b)

Gambar 5. Sebaran Frekuensi Berat Tubuh Scylla sp. Betina Hasil Tangkapan di Kawasan Perairan Kedungmutih, Kabupaten Demak Bulan Januari dan Februari Tahun 2017. Keterangan : (a) Bulan Januari (b) Bulan Februari 
Tabel 6. Presentase Tingkat Kematangan Gonad (Telur) Kepiting Bakau Betina (Scylla sp.)

\begin{tabular}{cccc}
\hline Waktu & TKG & Jumlah (ekor) & Presentase (\%) \\
\hline \multirow{3}{*}{ Januari } & I & 4 & $10 \%$ \\
& II & 19 & $47 \%$ \\
& III & 11 & $28 \%$ \\
& IV & 6 & $15 \%$ \\
\hline \multirow{3}{*}{ Februari } & I & 3 & $6 \%$ \\
& II & 19 & $35 \%$ \\
& III & 27 & $50 \%$ \\
& IV & 5 & $9 \%$ \\
\hline
\end{tabular}

Ket: TKG = Tingkat Kematangan Gonad

yang tinggi menyebabkan terjadi aktifitas fotosintesa fitoplankton yang selanjutnya menghasilkan zooplankton yang menjadi pakan alami bagi larva kepiting bakau (Scylla sp.) (Siahainenia, 2008).

Hal yang dapat menyebabkan morfometri berhubungan dengan tingkat kematangan gonad adalah ketersediaan sumber makanan yang berada di alam,karena kegiatan penangkapan yang dilakukan oleh nelayan menurun akibat cuaca buruk pada bulan Januari - Februari yang memasuki musim pancaroba sehingga ketersediaan jumlah kepiting yang berada di alam meningkat dan pada kepiting bakau betina yang bertelur dapat menumbuhkan telurnya tanpa ditangkap oleh nelayan. Pada proses pemijahan dapat berjalan dengan baik tanpa adanya gangguan dari nelayan sehingga penambahan individu yang berada di alam dapat berjalan dengan baik. Sumber makanan yang dibutuhkan oleh kepiting bakau pun dapat meningkat,sehingga menambah ukuran tubuh dan berat dari kematangan telur secara bersamaan dan dapat dikatakan kematangan telur dapat mempengaruhi morfometri yang terdapat pada kepiting bakau (Scylla sp.).

\section{KESIMPULAN}

Berdasarkan hasil penelitian dapat disimpulkan bahwa, dari sampel kepiting bakau betina Scylla sp yang didapat diperoleh hubungan antara morfometri dan tingkat kematangan telur. Sehingga, dapat dikatakan jika pada berat kepiting mengalami pembesaran maka pada telur yang berada di dalam tubuh kepiting bakau betina pun mengalami penambahan jumlah dan mengalami peningkatan kematangan telur (gonad).

\section{DAFTAR PUSTAKA}

Arikunto, S. 2002. Prosedur Penelitian Suatu Pendekatan Praktek. PT.Rineka Cipta, Jakarta

Catacutan, M.R. 2002. Growth and Body Composition of Juvenille Mud Crab, Scylla serrata, Fed Different Dietary Protein and Lipid Levels and protein to Energy Ratio. Aquaculture.

Effendie, M.I. 1997. Biologi Perikanan. Yayasan Pustaka Nusatama, Yogyakarta.
. 2002. Biologi Perikanan. Yayasan Pustaka Nusatama, Yogyakarta.

Hill, B.J. 1974. Salinity and temperature tolerance of zoea of The Portunid Crab Scylla serrata. Marine Biology.

.1982. Effects of temperature on feeding and activity in mud crab $S$. serrata, Marine Biology

Kasry, A. 1996. Budidaya Kepiting Bakau dan Biologi Ringkas. Bharata, Jakarta.

Nontji, A. 2005. Laut Nusantara. Djambatan, Jakarta.

Overton, J.L., Macintosh, D.J., \& Thorpe, R.S. 1997. Multivariate Analysis of The Mud Crab Scylla serrata (Brachiura: Portunidae) from Four Locations in South East Asia. Marine Biology.

Siahainenia, L. 2008. Bioekologi kepiting bakau (Scylla spp) di ekosistem mangrove Kabupaten Subang Jawa Barat.Disertasi. Program Pascasarjana Institut Pertanian Bogor.

Warner, G.F. 1977. The Biology of crabs.Elek Science, London. 